\title{
乾しいたけ中の亜硫酸含有量の実態調査
}

(昭和 62 年 8 月 24 日受理)

津村明宏* 平松絹子*

大西ミヤ子* 高 橋 鼎*

\section{Content of Sulfur Dioxide in Dried Shiitake (Lentinus edodes)}

\author{
Akihiro Tsumura, Kinuko Hiramatsu, Miyako Ohnishi and Kanae Takahashi
}

(Kobe Agricultural and Forestry Products Inspection Institute:

1-4, Onohama-cho, Chuo-ku, Kobe, Japan)

Key words: 亜硫酸 sulfur dioxide；レンチオニン lenthionine；改良ランキン法 modified Rankine method; 乾しいたけ dried shiitake

はじめに

亜硫酸及びその塩類は食品の漂白, 保存, 酸化防止な よ゙の目的で広く食品に使用され，その使用基準は 0.03 $\mathrm{g} / \mathrm{kg}$ から $5 \mathrm{~g} / \mathrm{kg}$ 以下まで 9 段階に分けて規制されて いる.

最近, 米国で亜硫酸がぜん息発作のイニシエーターと して作用していることが判明し, 昭和 61 年 7 月, FDA は二酸化イオウ $\left(\mathrm{SO}_{2}\right)$ として $10 \mathrm{ppm}$ 以上含有する食品 についてその表示を義務付けた ${ }^{11}$ 。この措置がとられた 後, 日本の輸出乾しいたけから高濃度の亜硫酸が検出さ れ問題となった。 そのため国内に流通する乾しいたけ (Lentinus edodes) についても, 亜硫酸の存在を調査し実 態を把握しておくことが急務と思われる.

亜硫酸の定量法として FDA では Monier-Williams 法占を採用しているが，分析に長時間を要し検出限界む $10 \mu \mathrm{g}$ 程度である.このほか蒸留比色法 ${ }^{3)}$, 微量拡散法 ${ }^{3)}$, 改良ランキン法年などがあるが，これらの方法の中では 迅速性, 再現性の点で改良ランキン法が優れていると考 えられる。

そこで著者らは改良ランキン法により乾しいたけ中の 亜硫酸のバックグラウンド調查を行い, 併せて定量時に おける妨害物質の検討も行ったので報告する.

\section{実験方法}

\section{1. 試料}

国内及び中国産の乾しいたけを対象としたが，それぞ れの産地，銘柄のはっきりしたものを求めるため神戸市 内のしいたけ問屋より購入した。

* 農林水産省神戸農林規格検查所：神戸市中央区小野浜町 14

\section{2. 試薬}

1\%アジ化ナトリウム溶液：アジ化ナトリウム（米山 薬品工業(株)製） $1 \mathrm{~g}$ をとり水を加えて溶かし $100 \mathrm{ml}$ とした.

5\%ジメドンーエタノール溶液：ジメドン（試薬特級, 和光純薬工業(株)製） $5 \mathrm{~g}$ をとり, エタノールを加えて 溶かし $100 \mathrm{ml}$ とした。

$25 \%$ リ酸溶液：リン酸（試薬特級） $100 \mathrm{ml}$ に水 240 $\mathrm{ml}$ を加えた。

シリコーン樹脂：食品添加物用シリコーン樹脂 KM72 (信越化学(株)製) を用いた。

発色液：塩酸パラロザニン（試薬特級） $40 \mathrm{mg}$ を塩酸 (試薬特級) $20 \mathrm{ml}$ に溶解し水を加え $100 \mathrm{ml}$ とし, $0.2 \%$ ホルムアルデヒド溶液 $100 \mathrm{ml}$ を混和した.

亜硫酸標準溶液：亜硫酸水素ナトリウム（試薬特級） $0.5 \mathrm{~g}$ をとり, 水で溶解し $100 \mathrm{ml}$ とした. その $10 \mathrm{ml}$ を とり, 常法 ${ }^{5}$ に従って標定し, $\mathrm{SO}_{2}$ として $300 \mu \mathrm{g} / \mathrm{ml}$ と なるように $0.1 N$ 水酸化ナトリウムで希釈し用時調製し た.

その他の試薬はすべて試薬特級を用い，水は用時蒸留 水を煮沸し脱気したものを用いた。

\section{3 . 器具及び装置}

亜硫酸定量装置：改良ランキン法装置

分光光度計：（株）日立製作所製 200-10 型

4. 分析方法

1 ）試験溶液の調製

ナシ型フラスコに $0.1 N$ 水酸化ナトリウム溶液 $10 \mathrm{ml}$ をとり定量装置に取り付ける。別に丸底フラスコに $5 \%$ ジメドンーエタノール溶液 $1 \mathrm{ml}, 1 \%$ アジ化ナトリウム 1 $\mathrm{ml}$, 水 $20 \mathrm{ml}$, エタノール $2 \mathrm{ml}$ 及び $25 \%$ リ酸 $10 \mathrm{ml}$ 
をとりシリコーン樹脂 2 滴を加え, 装置に取り付け窒素 を $500 \mathrm{ml} / \mathrm{min}$ の速度で 5 分間通気する. その後細切し た試料 $1 \mathrm{~g}$ を丸底フラスコに加え，窒素を通気しながら 20 分間ミクロバーナーで加熱し, 発生した $\mathrm{SO}_{2}$ を $0.1 N$ 水酸化ナトリウム溶液に捕集し試験溶液とした。

2 ）比色定量

試験溶液 $5 \mathrm{ml}$ をとり, 発色液 $1 \mathrm{ml}$ を加えよく振り混 ぜた後, 室温で 35 分間放置したものについて波長 580 nm における吸光度を測定した.

また，亜硫酸標準溶液を $0.5 〜 2.0 \mu \mathrm{g} / \mathrm{ml}$ となるよう $0.1 N$ 水酸化ナトリウム溶液でそれぞれ希釈し，その各 5

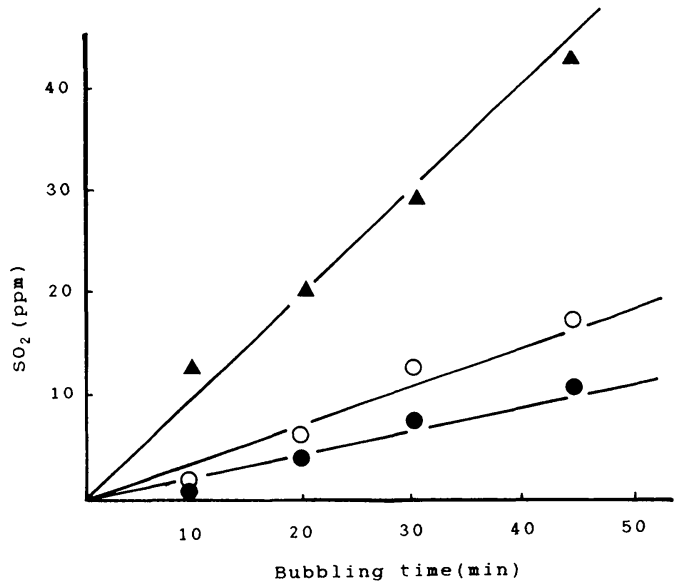

Fig. 1. Effect of bubbling time and determination of sulfur dioxide in dried shiitake

- - Japanese dried shiitake (whole) $\bigcirc-\bigcirc$ : Japanese dried shiitake (powder) $\Delta-\mathbf{\Delta}$ : Chinese dried shiitake (whole) $\mathrm{ml}$ をとり, 同様に発色させ検量線を作成し, 試料中の亜 硫酸含量を算出した。

なお，本法の検出限界は $2.5 \mathrm{ppm}$ 以上の場合に信頼性 があると報告されていること出から $2.5 \mathrm{ppm}$ 以下の測定 值は検出しないこととした。

\section{結果及び考察}

\section{1 。通気時間による測定値の影響}

通気時間が測定值に与える影響を調べるため，3 種類 の乾しいたけを用い通気時間を変え亜硫酸を測定した結 果はFig. 1 のとおりである.

各種乾しいたけ中の亜硫酸量は通気時間の経過と共に 増加する傾向が見られ, 特に中国産のものがその増加量 は大きかった。従来の文献5),6)では食品からの亜硫酸の 留出は 10〜20 分でほぼ完了すると報告されていること から，少なくとも通気時間が 20 分以降に測定された亜 硫酸は通気中に生成した亜硫酸もしくは妨害物質の影響 と推測された。

\section{2. 添加回収実験}

次に亜硫酸の留出傾向を調べるために日本産乾しいた けに標準亜硫酸溶液を添加し，窒素の通気時間を変えた ときの回収率を Table 1 に示した。標準溶液では通気時 間 10 分でほぼ留出したが，試料では 30 分間通気して も回収率は低かった。

亜硫酸塩類を食品に添加した場合，食品中のアルデヒ ド，ケトン及び糖と結合し, 結合型亜硫酸として食品中 に存在することが知られている5). このような結合型覀 硫酸であっても通気時間 20 分までに亜硫酸の留出は完

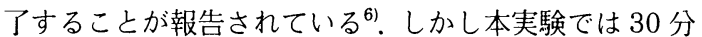
通気しても十分な回収率が得られなかったことから，ア ルデヒドなどより結合力の強い成分が乾しいたけ中に存

Table 1. Recovery Test of Sulfur Dioxide

\begin{tabular}{|c|c|c|c|c|c|}
\hline \multirow{2}{*}{ Sample } & \multirow{2}{*}{$\begin{array}{l}\text { Added } \mathrm{SO}_{2} \\
(\mu \mathrm{g})\end{array}$} & \multicolumn{2}{|r|}{$5^{*}$} & \multicolumn{2}{|c|}{$10^{*}$} \\
\hline & & Found & Recovery & Found & Recovery \\
\hline \multirow{4}{*}{$\begin{array}{l}\text { Standard } \\
\text { Dried shiitake }\end{array}$} & 500 & 434 & $86.8 \pm 2.5$ & 494 & $98.8 \pm 1.1$ \\
\hline & 500 & 120 & $24.0 \pm 3.1$ & 226 & $45.2 \pm 4.9$ \\
\hline & 20 & 2.4 & $12.0 \pm 4.9$ & 12.1 & $51.6 \pm 7.6$ \\
\hline & 0 & 0 & - & 1.8 & - \\
\hline \multirow{2}{*}{ Sample } & \multirow{2}{*}{$\begin{array}{c}\text { Added } \mathrm{SO}_{2} \\
(\mu \mathrm{g})\end{array}$} & \multicolumn{2}{|c|}{$20 *$} & \multicolumn{2}{|c|}{$30 *$} \\
\hline & & Found & Recovery & Found & Recovery \\
\hline Standard & 500 & 520 & $104.0 \pm 2.7$ & 519 & $103.9 \pm 3.1$ \\
\hline \multirow[t]{3}{*}{ Dried shiitake } & 500 & 226 & $45.2 \pm 4.9$ & 316 & $63.2 \pm 1.8$ \\
\hline & 20 & 17.6 & $61.5 \pm 10.0$ & 18.3 & $61.7 \pm 6.5$ \\
\hline & 0 & 5.3 & - & 6.0 & - \\
\hline
\end{tabular}

Each value was the mean of three trials.

* Bubbling time (min) 
Table 2. Effect of Volatile Sulfur Compounds

\begin{tabular}{lcc}
\hline Sulfur compound & $\begin{array}{c}\text { Added } \\
(\mathrm{mg})\end{array}$ & $\begin{array}{c}\text { Found } \mathrm{SO}_{2} \\
(\mathrm{ppm})\end{array}$ \\
\hline Hydrogen sulfide* & 2.0 & 11.0 \\
Hydrogen sulfide* & 20.0 & 26.6 \\
Carbon disulfide & 0.5 & 0.0 \\
Lenthionine & 0.4 & 4.1 \\
Lenthionine & 2.0 & 6.9 \\
\hline
\end{tabular}

* Iron( II ) sulfide was used.

Table 3. Change of Sulfur Dioxide by Soaking in Water or Heating

\begin{tabular}{|c|c|}
\hline Method of treating & Found $\mathrm{SO}_{2}(\mathrm{ppm})$ \\
\hline Control & 8.0 \\
\hline Soaking $0.3 \mathrm{hr}$ & 14.2 \\
\hline Soaking $3 \mathrm{hr}$ & 34.4 \\
\hline Soaking $24 \mathrm{hr}$ & 34.2 \\
\hline Heating $10 \mathrm{~min} *$ & 15.2 \\
\hline Heating $30 \mathrm{~min} *$ & 8.1 \\
\hline Heating $60 \mathrm{~min} *$ & 7.3 \\
\hline
\end{tabular}

$*$ Refluxed in water bath at $100^{\circ} \mathrm{C}$
在し，加熱・通気によっても添加した亜硫酸が留出され ないことが原因と考えられた。

\section{3. 揮発性イオウ化合物の影響}

改良ランキン法はイオウ化合物の影響が少ないとされ ているが7)，揮発性イオウ化合物の影響について調べた 結果は Table 2 に示したように硫化水素はプラスに妨害 していた.

また乾しいたけ特有香気成分の一つにイオウ化合物で あるレンチオニン息があるが， レンチオニンもプラスに 妨害していることが分かった。 すなわちレンチオニンそ のものに発色液を加えても発色しなかったことから，レ ンチオニン自体は発色には関与しないことが明らかにな った。しかしレンチオニンは加熱分解して硫化水素が発 生する ${ }^{9)} と と ， \quad$ 硫化水素そのものはプラスに妨害する ことから亜硫酸測定中にレンチオニンの熱分解によって 硫化水素が発生し，測定値に影響を及ぼしているものと 考えられた。

すなわち測定中に乾しいたけが水を吸収し，それに含 まれるレンチニン酸の酵素分解によって生成したレンチ オニン ${ }^{11}$ 由来の硫化水素が妨害しているものと考えられ た.

他に乾しいたけ中に天然に存在すると言われている二

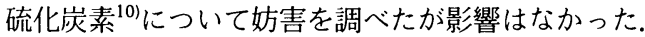

4. 加熱, 水浸による亜硫酸含量の変化

乾しいたけを加熱あるいは水に浸すことに伴う亜硫酸

Table 4. Contents of Sulfur Dioxide in Each Kind of Dried Shiitake

\begin{tabular}{ccc}
\hline \hline District of product & Kind of dried shiitake & Found $\mathrm{SO}_{2}(\mathrm{ppm})$ \\
\hline China & Donko & $8.0 \pm 0.9$ \\
China & Donko & $14.8 \pm 3.3$ \\
China & Donko & $19.8 \pm 1.5$ \\
China & Donko & $17.0 \pm 4.5$ \\
Mie & Donko & $13.0 \pm 2.0$ \\
Mie & Koko & $9.3 \pm 1.3$ \\
Mie & Koshin & $5.4 \pm 0.7$ \\
Ehime & Donko & $7.6 \pm 3.4$ \\
Ohita & Donko & $5.9 \pm 0.6$ \\
Ohita & Koko & $8.7 \pm 0.3$ \\
Fukushima & Donko & $8.3 \pm 1.0$ \\
Fukushima & Donko & $10.0 \pm 1.0$ \\
Shiga & Donko & $4.8 \pm 1.6$ \\
Tottori & Donko & $10.4 \pm 0.4$ \\
Nara & Donko & $13.1 \pm 2.8$ \\
Okayama & Donko & $6.8 \pm 4.0$ \\
Shimane & Donko & $7.9 \pm 2.9$ \\
Yamaguchi & Donko & $3.6 \pm 1.6$ \\
Tsushima & Donko & N.D. \\
Hyogo & Koko & N.D. \\
\hline
\end{tabular}

N.D.: Not detected (detection limit $2.5 \mathrm{ppm}$ )

Each value was the mean of three trials. 
の変化を調べ，この結果を Table 3 に示した. 試料の調 製方法は加熱については試料 $1 \mathrm{~g}$ をとり水 $20 \mathrm{ml}$ を加 え, 沸とう水浴中にて加熱を行った。水浸の場合は試料 $1 \mathrm{~g}$ に水 $20 \mathrm{ml}$ を加え密栓し, 室温放置した. 後加熱, 水浸ともナシ型フラスコに試料をとり, 試薬を加え 20 分間通気，加熱を行った.

水浸の場合 20 分程度の放置では亜硫酸量の増加は少 ないが, 3 時間経過すると急激に増加し 24 時間放置後 もほぼ一定の值を保った. 安木ら ${ }^{11}$ は乾しいたけを水に 浸すことにより，L- $\gamma$-glutamyl-L-cysteine sulfoxide の $S$ 置換体誘導体であるレンチニン酸から酵素的にレンチ オニンが生成することを報告していることから水浸によ る亜硫酸量の増加は乾しいたけを水に浸すことにより酵 素分解によってレンチオニンが生成したものと考えられ た.

一方加熱時間 10 分では亜硫酸量は増加するが, 30 分 以上加熱したものは対照と同レベルの值となったここの 加熱による増減の原因は水を加えることにより生成した レンチオニンが加熱することによって揮散したこと, 及 びレンチオニン生成酵素の加熱による失活が考えられ た.

\section{5. 各種乾しいたけ中の亜硫酸のバックグラウンド} 調查

産地・銘柄のはっきりしている乾しいたけ 20 検体に ついて亜硫酸含有量を測定した結果を Table 4 に示す. 中国産は 8.0〜 $19.8 \mathrm{ppm}$ (平均 $14.9 \mathrm{ppm}$ ), 日本産は

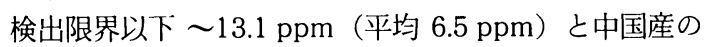
方がやや高い值を示し, サンプル間のばらつきは大きか った。 中国産乾しいたけが高い值を示す原因については 今後検討してゆく予定である.

要 約

1. 乾しいたけ中亜硫酸のバックグラウンド調査を行 った結果, 検出限界以下〜19.8 ppm であった. 特に中
国産が日本産に比べ高い值を示した。

2. 揮発性イオウ化合物では硫化水素が測定をプラス に妨害すること，また乾しいたけの香気成分であるレン チオニンも測定を妨害することが分かった。

3. 亜硫酸測定值は通気時間 45 分までの範囲で増加 する傾向があり, 特に中国産が日本産に比べ顕著であっ た.

4.乾しいたけを水に浸すことで亜硫酸は増加し, 加 熱によって減少した。

\section{文献}

1）農政調查委員会編：“食の科学” 109, 96～99 (1987), 光 琳.

2) William, H.: J. Assoc. Off. Anal. Chem. 30, 339 340 (1980).

3）日本薬学会編：“衛生試験法注解” p. 187 (1973), 金原出 版.

4) Ogawa, S., Suzuki, H., Toyoda, M., Ito, Y., Iwaida, M., Nonogi, H., Fuke, T., Obara, K., Adachi, T., Fujita, K., Ikuzawa, M., Izumi, T., Hamano, T., Mitsuhashi, Y., Matsuki, Y: Z. Lebensm. Unters. Forsch., 168, 293 298 (1979).

5）厚生省環境衛生局食品化学課：“食品中の食品添加物分析 法” p. 74 84 (1982), 講談社.

6）宮本文夫, 佐伯政信：日食工誌. 31, 739～745 (1984).

7) Mitsuhashi, Y., Hamano, T., Hasegawa, A., Tanaka, K., Matsuki, Y., Adachi, T., Obara, K., Nonogi, H., Fuke, T., Ikuzawa, M., Fujita, K., Izumi. T., Ogawa, S., Toyoda, M., Ito, Y., Iwaida, M.: Z. Lebensm. Unters. Forsch. 168, 299 304 (1979).

8）安木教傳: 化学と生物 16, 361 362 (1978).

9）和田正三, 中谷弘美, 富士繩昭平, 木村 博, 芳谷道男: 栄養と食糧 20, 355 359 (1967).

10）豊田正武：化学と生物 15, 707～709 (1977).

11) Yasumoto, K., Iwami, K., Mitsuda, H.: Agric. Biol. Chem. 35, 2070 2080 (1971). 